\title{
First morphometry, reproduction, and genetic data for Blennius ocellaris (Linnaeus, 1758) from the Black Sea
}

\author{
Uğur KARADURMUŞ ${ }^{1}$, Rafet Çağrı ÖZTÜRK², Mehmet AYDIN ${ }^{3}$
}

Cite this article as:

Karadurmuş, U., Öztürk, R.Ç., Aydın, M. (2022). First morphometry, reproduction, and genetic data for Blennius ocellaris (Linnaeus, 1758) from the Black Sea. Aquatic Research, 5(1), 53-62. https://doi.org/10.3153/AR22006

\footnotetext{
Bandırma Onyedi Eylül University, Maritime Vocational School, Department of Underwater Technology, Balıkesir, Turkey

${ }^{2}$ Karadeniz Technical University, Faculty of Marine Sciences, Department of Fisheries Technology Engineering, Trabzon, Turkey

${ }^{3}$ Ordu University, Fatsa Faculty of Marine Sciences, Department of Fisheries Technology Engineering, Ordu, Turkey
}

\section{ORCID IDs of the author(s):}

U.K. 0000-0002-5827-0404

R.Ç.Ö. 0000-0003-1785-4056

M.A. 0000-0003-1163-6461

Submitted: 24.08 .2021

Revision requested: 29.09 .2021

Last revision received: 30.09 .2021

Accepted: 06.10.2021

Published online: 26.12 .2021

Correspondence:

Mehmet AYDIN

E-mail: maydin69@hotmail.com

\begin{abstract}
Two specimens of the butterfly blenny, Blennius ocellaris, were caught off the coast of Ordu (Black Sea, Turkey) in April 2021 by trammel net. The aim of this paper is to further document occurrence and distribution of the butterfly blenny for the Black Sea and for Turkish marine ichthyofauna and to provide first morphometric, reproduction, and genetic data on this species to the Black Sea fauna species. Some morphometric and meristic characters were measured and presented as the percentage of total length (TL\%). All morphometric measurements except eye diameter, pre-anal length, and maximum body depth were higher in the male individual. It was observed that the head makes up almost 1/4 of the body. It was determined that the ripe eggs were in their final stage of development (Stage IV). Gonad's weight of a female individual was $2.85 \mathrm{~g}$ and the number of eggs was determined as 2993 . The mean egg diameter was measured as $1070.7 \pm 15.63$ $\mu \mathrm{m}$ (from 1050.2 to $1123.1 \mu \mathrm{m}$ ). The mitochondrial DNA gene regions of 16S rRNA and COI of the specimens were sequenced and analyzed. The generated partial sequences of COI and $16 \mathrm{~S}$ rRNA were $621 \mathrm{bp}$ and $551 \mathrm{bp}$, respectively. The maximum likelihood tree generated with the $\mathrm{COI}$ gene sequences retrieved from the GenBank database demonstrated geographic region-based distinction and sequences of the Black Sea specimens nested with the reference specimen sequences from the Western Mediterranean Sea and the Sea of Marmara.
\end{abstract}

Keywords: Butterfly blenny, Black Sea, Ichthyofauna, Morphology, Reproduction, mtDNA 


\section{Introduction}

The butterfly blenny, Blennius ocellaris (Linnaeus, 1758) (Family: Blenniidae), is a demersal species inhabiting inshore waters. This species is widespread from the English Channel to Morocco and throughout the Mediterranean Sea and parts of the Red Sea. It is found especially over rocky substrates covered with seaweed. It is commonly found from 30 to 200 $\mathrm{m}$ depth, up to $400 \mathrm{~m}$ on the Algerian coast (Zander, 1986). $B$. ocellaris is a carnivorous and nocturnal fish that mainly feed on small fish, polychaetes, mollusks, crustaceans, echinoderms, bryozoans, and ascidiaceans (Kabasakal, 1999). Eggs that are demersal and adhesive, are laid under musselshells or stones and guarded by male. Depending on the water temperature, spawning takes place between April (Marseille) and July (England). Larvae are planktonic and often found in shallow coastal waters (Watson, 2009). It may sometimes be captured as a bycatch in bottom trawlers. It was caught as bycatch in about $37 \%$ of experimental trawls conducted in the Aegean Sea, but was not abundant (Damalas et al., 2010).

Little is known about the distribution and habitats of butterfly blenny. The occurrence of $B$. ocellaris was reported from the Mediterranean Sea (Başusta \& Erdem, 2000; Çiçek et al., 2006), the Aegean Sea (Kabasakal, 1999; Torcu \& Aka, 2000; Acarl1 et al., 2014; Bilge et al., 2014; Coker and Cihangir, 2018; Illkyaz et al., 2018), the Sea of Marmara, and Turkish Straits (Slastenenko, 1959; Moosleitner, 1988; Bok et al., 2011; Daban et al., 2020). This species is also globally listed as Least Concern (LC) in the IUCN Red List of Threatened Species (Di Natale et al., 2014). The occurrence of $B$. ocellaris in the Black Sea was first mentioned in the marine fish checklist for Black Sea without species description by Bilecenoğlu et al. (2014) referring Erazi (1942). The species has also been reported on the coasts of the Bulgaria (Zander, 1986) and Ukraine (Rass, 1987) in the Black Sea. Lastly, Bat et al. (2005) reported the presence of the species in their fauna studies on Sinop coasts, Turkey (central Black Sea). Moreover, the butterfly blenny was described as a rare species in the Black Sea and listed as endangered (EN: high risk of extinction in the wild) for Turkish Black Sea coast by the Black Sea Commission (BSC, 2021). There is no scientific evidence of the presence of the species in the Black Sea other than cited literatures. Nevertheless, none of the scientific data in the Black Sea provides the data on capture sites, capture depths, sizes of fish, morphological characters and genetic characterization. Morphological characters, such as meristic counts and body shape, have long been used in stock identification (Haddon \& Willis, 1995; Turan et al., 2004). The aim of this paper is to further document butterfly blenny for the Black Sea and for Turkish marine ichthyofauna and to provide first morphometric, reproduction, and genetic data on this species to the Black Sea fish fauna.

\section{Material and Methods}

\section{Sampling and Morphology}

A single male and female $B$. ocellaris specimens were caught in the southern Black Sea coast of Ordu, Turkey $\left(41^{\circ} 02^{\prime} 14.89^{\prime \prime} \mathrm{N}-37^{\circ} 30^{\prime} 02.80^{\prime \prime} \mathrm{E}\right)$ on 21-22 April 2021 (Figure 1). The individuals were captured as a discard during red mullet fisheries by commercial trammel nets with $28 \mathrm{~mm}$ mesh size on the sandy seabed at $50 \mathrm{~m}$ depth. Specimens were morphologically identified at species level according to the main references (Fischer et al., 1987; Uiblein \& Heemstra, 2010). Taxonomic classification was determined according to FishBase (Froese \& Pauly, 2019) as: Animalia (Kingdom); Chordata (Phylum); Actinopterygii (Class); Blenniiformes (Order); Blenniidae (Family); Blenniinae (Subfamily); Blennius (Genus); B. ocellaris (Species); B. lepus, Adonis pavoninus (Synonymus). The sex of each specimen was determined by macroscopic gonadal examination. Morphometric and meristic characters were measured on each specimen according to Gharaei (2012). Different morphometric characteristics were calculated as the percentage of total length (TL\%) (Gaygusuz et al., 2006). Morphological characters were measured in the laboratory with an electronic caliper to the nearest $0.01 \mathrm{~mm}$ and weight of specimens were weighed to the nearest $0.01 \mathrm{~g}$. In order to determine reproduction characteristics, eggs were weighed on a balance with a sensitivity of $0.001 \mathrm{~g}$. The egg size and number of eggs were determined from egg subsamples according to Bagenal (1978) and Murua et al. (2003). For egg diameter inspection, diameter was measured with a calibrated ocular microscope using imaging software (Nikon NIS Elements 3.0) to the nearest $0.01 \mu \mathrm{m}$ (Jakobsen et al., 2009).

\section{Genetic Analysis}

The genomic DNA was extracted from fin clips using Genomic DNA purification kit (SV Wizard, Promega). The integrity and concentration of the DNA was assessed with gel electrophoresis. Two mtDNA gene regions; 16S rRNA and cytochrome oxidase subunit-I (COI) were analyzed for genetic characterization and species identification. PCR assay was performed in a total volume of $25 \mu$ l containing, $12.5 \mu 1$ 2X PZR mastermix (Hibrigen), $1 \mu 1$ of each primer ( $10 \mathrm{pmol})$, $100 \mathrm{ng}$ DNA and ultrapure water. The primers of $16 \mathrm{Sbr}-\mathrm{H}$ and 16Sar-L (Palumbi, 1996) were used to amplify 16S rRNA gene region. The primers of Fish-F1 and Fish-F2 (Ward et al. 2005) were used to amplify COI gene region. The thermal cycling condition was as follows: $95^{\circ} \mathrm{C}$ for $3 \mathrm{~min}$, followed 
by 35 cycles of $95^{\circ} \mathrm{C}$ for $50 \mathrm{~s}, 54^{\circ} \mathrm{C}-55^{\circ} \mathrm{C}(16 \mathrm{~S}$ rRNA and COI) for $45 \mathrm{~s}$, and $72^{\circ} \mathrm{C}$ for $45 \mathrm{~s}$ with a final extension step of $5 \mathrm{~min}$ at $72^{\circ} \mathrm{C}$. PCR products were visualized on agarose gel and sequenced on ABI 3500 Genetic Analyzer (Thermo Fisher) using a Big Dye v.3.1 Terminator Cycle Sequencing Kit.

The raw sequence reads were manually checked, trimmed, and aligned using BioEdit (Hall, 1999). The quality checked sequence data was compared with reference sequences in the NCBI GenBank database (https://www.ncbi.nlm.nih.gov) using BLAST (Basic Local Alignment Search Tool). Species assignment was performed based on the sequence similarity comparison.
The phylogenetic relationships were inferred with a maximum likelihood tree using available COI and 16S rRNA sequences of the species with known geographic information. The reference COI sequences (MG837120, MG837122, KJ709487, KY176406, JQ774790, KJ205345, JQ774787, KJ768218) and 16S rRNA sequence (AY098815) of B. ocellaris were retrieved from NCBI GenBank database. Salaria pavo (MH190459) was used as an outgroup. The maximum likelihood trees were generated in Mega X (Kumar et al., 2018). The robustness of the trees was tested with 1000 bootstrap replicates. The best suitable sequence evolution model was chosen based on the Akaike Information Criterion (AIC) and Bayesian Information Criterion (BIC).

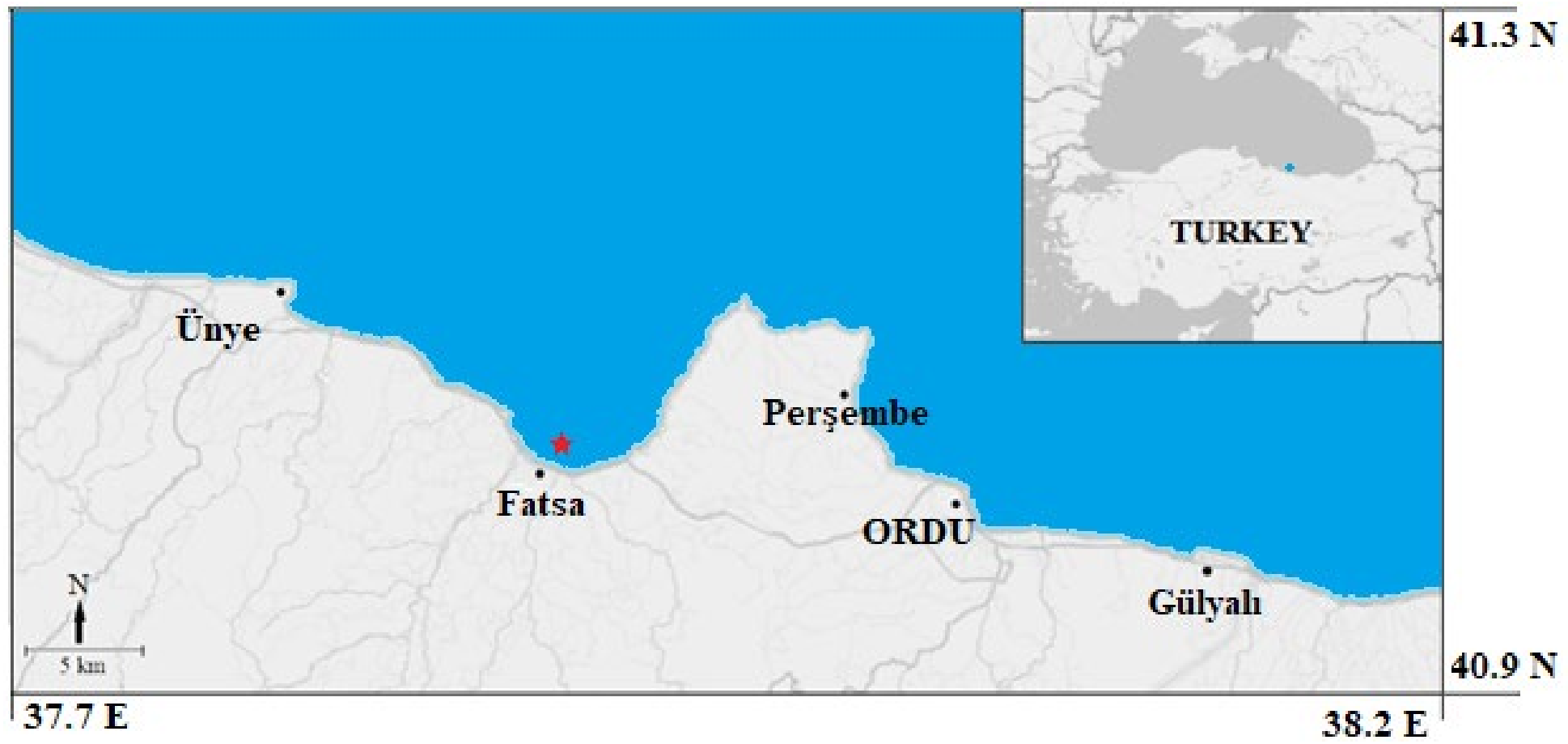

Figure 1. Sampling site. The red star in the figure represents the capture site $\left(41^{\circ} 02^{\prime} 14.89^{\prime \prime} \mathrm{N}-37^{\circ} 30^{\prime} 02.80^{\prime \prime} \mathrm{E}\right)$. 


\section{Results and Discussion}

\section{Description}

Dorsal fin rays XII +15 ; anal fin rays II +15 ; pectoral fin rays 12; pelvic fin rays $\mathrm{I}+3$. Anterior part of the dorsal fin is conspicuously longer than the posterior part. These features were similar in male and female individuals. Basic coloration was brown and yellowish for male and female, respectively. Five or seven distinctly dark bars on the body. There was a black spot with white margin between 6th and 8th dorsal fin rays of both male and female. The white margin was more pronounced in the female. This dark spot on the dorsal fin is a known characteristic feature of $B$. ocellaris (Figure 2).

\section{Morphology}

The lists of morphometric and meristic characters used for the analysis of B. ocellaris are presented in Table 1. All morphometric measurements except eye diameter, pre-anal length and maximum body depth were higher in male individual. The TL\% of all fins were also higher in male. It was observed that the head makes up almost $1 / 4$ of the body. The body height of the female is apparently higher (with the highest difference rate of $5.51 \%$ ) than that of the male. Therefore, the observed differences in TL\% can be characterized by gender; especially by body depth. Nevertheless, studies with a sufficient sample size are needed to be able to make a definite determination.

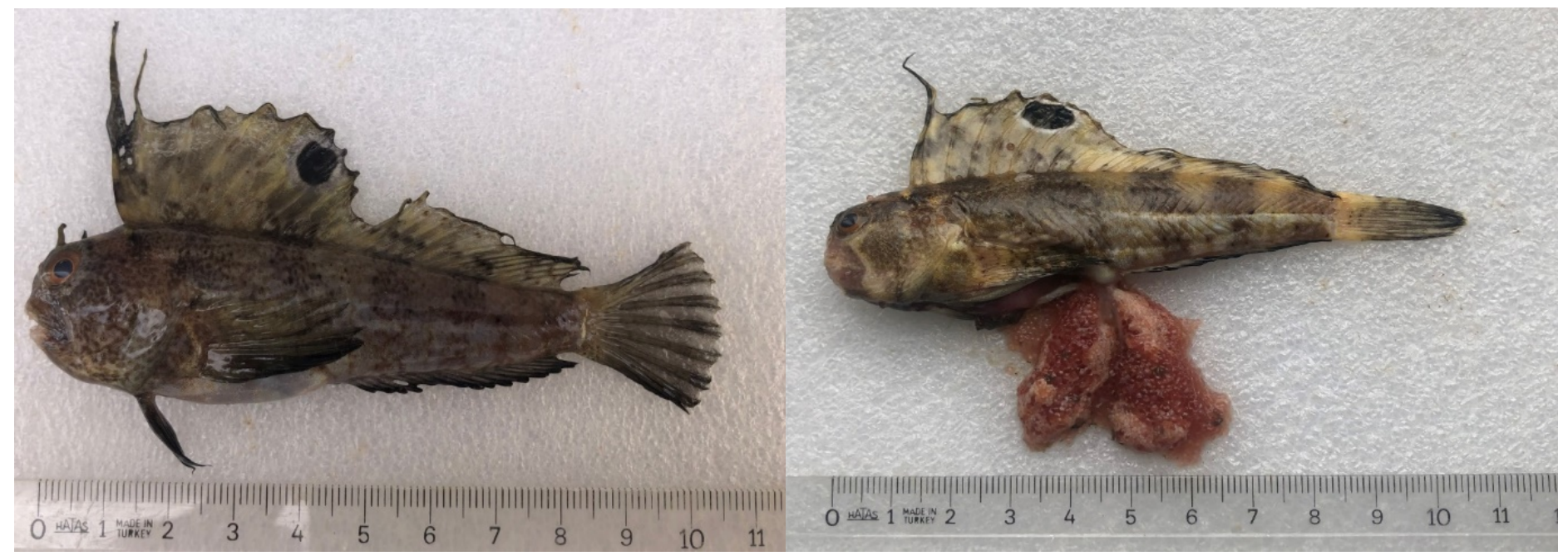

Figure 2. Male (left) and female (right) view of the sampled butterfly blenny, Blennius ocellaris, in the central Black Sea.

Table 1. Some morphometric and meristic properties of sampled Blennius ocellaris

\begin{tabular}{lcccc}
\hline \multirow{2}{*}{ Morphometric characters } & \multicolumn{2}{c}{ Male } & \multicolumn{2}{c}{ Female } \\
\cline { 2 - 5 } & Value & TL\% & Value & TL\% \\
\hline Total length (mm) & 105.20 & - & 104.00 & - \\
Standard length (mm) & 84.12 & 79.96 & 82.00 & 78.85 \\
Head length (mm) & 23.34 & 22.19 & 22.60 & 21.73 \\
Post-orbital length (mm) & 13.85 & 13.17 & 12.47 & 11.99 \\
Eye diameter (mm) & 5.80 & 5.51 & 5.75 & 5.53 \\
Pre-dorsal length (mm) & 19.48 & 18.52 & 17.77 & 17.09 \\
Dorsal fin base length (mm) & 65.13 & 61.91 & 64.17 & 61.70 \\
Pre-anal length (mm) & 46.00 & 43.73 & 45.91 & 44.14 \\
Anal fin base length (mm) & 34.00 & 32.32 & 33.47 & 32.18 \\
Pre-pelvic length (mm) & 20.67 & 19.65 & 19.72 & 18.96 \\
Pelvic fin length (mm) & 16.72 & 15.89 & 16.47 & 15.84 \\
Pre-pectoral length (mm) & 25.44 & 24.18 & 23.32 & 22.42 \\
Pectoral fin base length (mm) & 23.74 & 22.57 & 22.86 & 21.98 \\
Max. body depth (mm) & 21.73 & 20.66 & 27.22 & 26.17 \\
Min. caudal peduncle depth (mm) & 8.59 & 8.17 & 7.57 & 7.28 \\
\hline Body weight (g) & 14.78 & - & 16.06 & - \\
\hline
\end{tabular}




\section{Reproduction}

Ovary became more enlarged occupying almost the entire body cavity and eggs were macroscopic and clearly visible. Ripe eggs were large transparent, red-whitish in color with conspicuous partially blood vessels (Figure 3). The gonad weight of the female individual was weighed as $2.85 \mathrm{~g}$ and the number of eggs was determined as 2993 . The egg diameter ranged from 1050.2 to $1123.1 \mu \mathrm{m}$, with an average size of $1070.7 \pm 15.63 \mu \mathrm{m}$.

\section{Genetic Characterization}

Two mtDNA gene regions of the two specimens were successfully sequenced. The generated partial sequences of COI and 16S rRNA were $621 \mathrm{bp}$ and $551 \mathrm{bp}$, respectively. A single haplotype for COI and 2 haplotypes for 16S rRNA were identified. Comparison of COI and 16S rRNA sequences against the GenBank database using BLAST gave a successful match with available $B$. ocellaris sequences with pairwise sequence identity similarity of $99.52 \%$ for COI and $99.82 \%$ $100 \%$ for $16 \mathrm{~S}$ rRNA genes. Generated COI and $16 \mathrm{~S}$ rRNA sequences were deposited in GenBank (Accession numbers: COI, MZ822975; 16S rRNA, MZ823046-MZ823047). There was only a single reference sequence of $16 \mathrm{~S}$ rRNA of $B$. ocellaris. Thus, maximum likelihood tree was only generated with COI gene region using Kimura two-parameter (K2P) model.

The topology of tree generated with Maximum Likelihood (ML) method with available COI ingroup references of $B$. ocellaris and outgroup (S. pavo) retrieved from GenBank database clearly recovered geographic region-based grouping. The Black Sea $B$. ocellaris genotype nested with the reference sequences generated from the specimens sampled from the Western Mediterranean Sea and the Sea of Marmara populations. Whereas reference sequences from the Atlantic Ocean and the North Sea were nested separately (Figure 4).

Upon evaluating the occurrences reported for the butterfly blenny in the Black Sea and the coastal waters of Turkey in Table 2, it was determined that the populations of the species in the Black Sea have not been described before. As we mentioned in the introduction section, presence of the butterfly blenny has been reported from the western (Erazi, 1942) and central (Sinop region) (Bat et al., 2005) Black Sea. Yet, there is no information about its morphometry, reproduction, and genetic properties of $B$. ocellaris for the Black Sea. The factors affecting growth and distribution of a fish species could be stated as nutrient availability, feeding, oxygen, salinity, temperature, pollutants, and predator density (Helfman et al., 2009). The fact that the female individual obtained in this study has ripe (eyed) eggs indicates that butterfly blenny is in the reproductive period in April in the Black Sea. Looking at the appearance of the ripe eggs, the maturity stage fits the IV stage definition (Carrasson \& Bau, 2003). The findings of Illkyaz et al. (2018) in the Aegean Sea confirm our determination regarding the reproduction period. They reported that the spawning of $B$. ocellaris occurs from January to May in İzmir Bay (Aegean Sea) and found that the first maturity length was $10.02 \mathrm{~cm}$ (3-years old).

Blenniiformes is a rich taxon and comprise over 150 genera and 900 species found in different aquatic ecosystems. Despite being diverse, there are limited number of genetic studies on blennies. Previously $B$. ocellaris was subjected to phylogenetic and DNA barcoding studies. Almada et al. (2005) assessed phylogenetic structure of 27 blennioid species including $B$. ocellaris distributed in the Mediterranean Sea and the Northeastern Atlantic Ocean based on 12S rRNA and 16S rRNA gene sequences. Distribution and presence of $B$. ocellaris was identified based on DNA barcoding studies in the Mediterranean Sea (Lanti et al., 2014; Vecchioni et al., 2018), the North Sea (Knebelsberger et al., 2012), and the Atlantic Ocean (Costa et al., 2012). Yet there is no genetic study on $B$. ocellaris in Turkish coastal waters. The mtDNA sequence data generated in the present study would contribute to the reference libraries for 16S rRNA, COI, and Turkish ichthyofauna.

There are no comprehensive studies regarding the ichthyofauna, especially on Blenniidae, of the Turkish coasts of the Black Sea. In this paper, the first basic morphological, genetic, and reproduction aspects of butterfly blenny were recorded in the Black Sea. The result of the present study indicates that the $B$. ocellaris has adapted to the region and that matured individuals have realized the activity of reproduction. Thus, the presence of the species in the eastern Black Sea indicates residency of the species in the region. Furthermore, there is a lack of information on age, growth, mortality, and diet of this species in coastal waters in Turkey. Additional biological and ecological studies on $B$. ocellaris would contribute biodiversity of the Black Sea. 


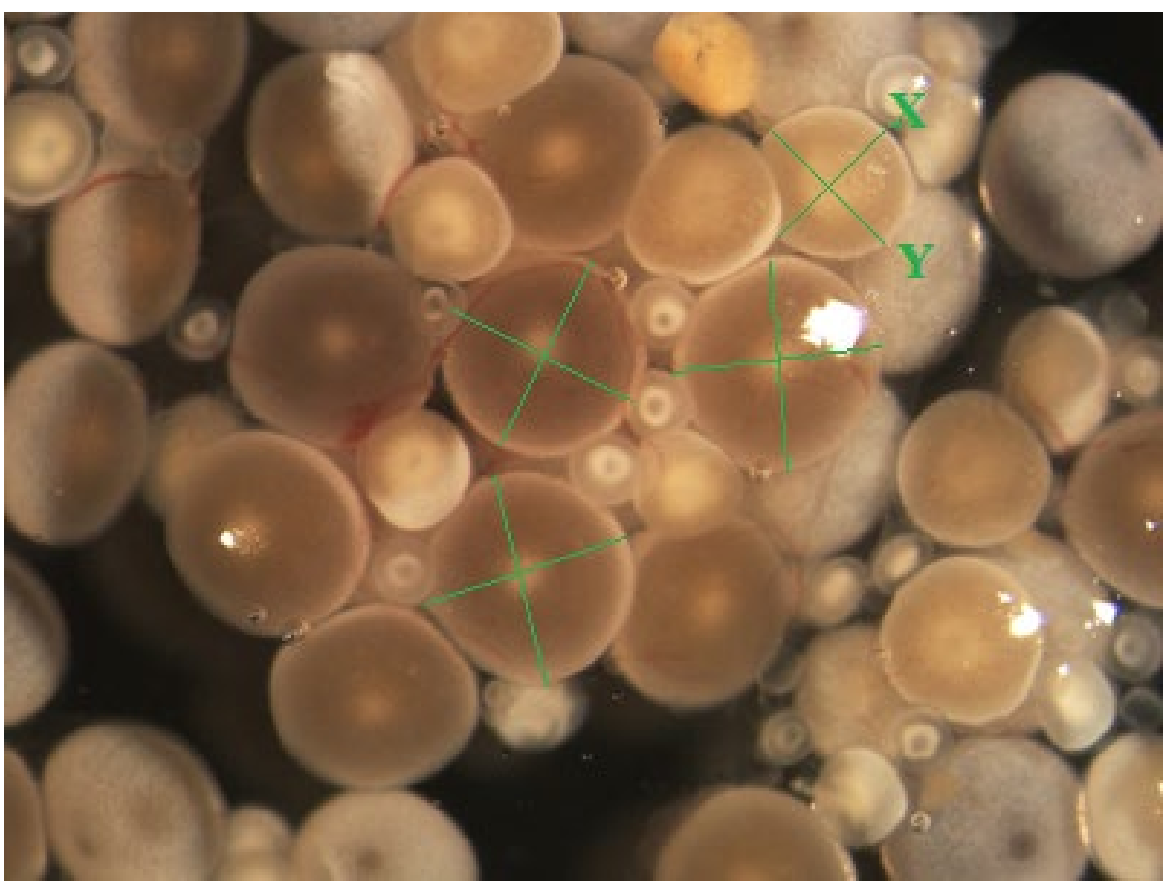

Figure 3. Ripe eggs of matured butterfly blenny (Stage IV according to Carrasson and Bau, 2003). Green lines represent long (X) and short (Y) axes of egg size measures.

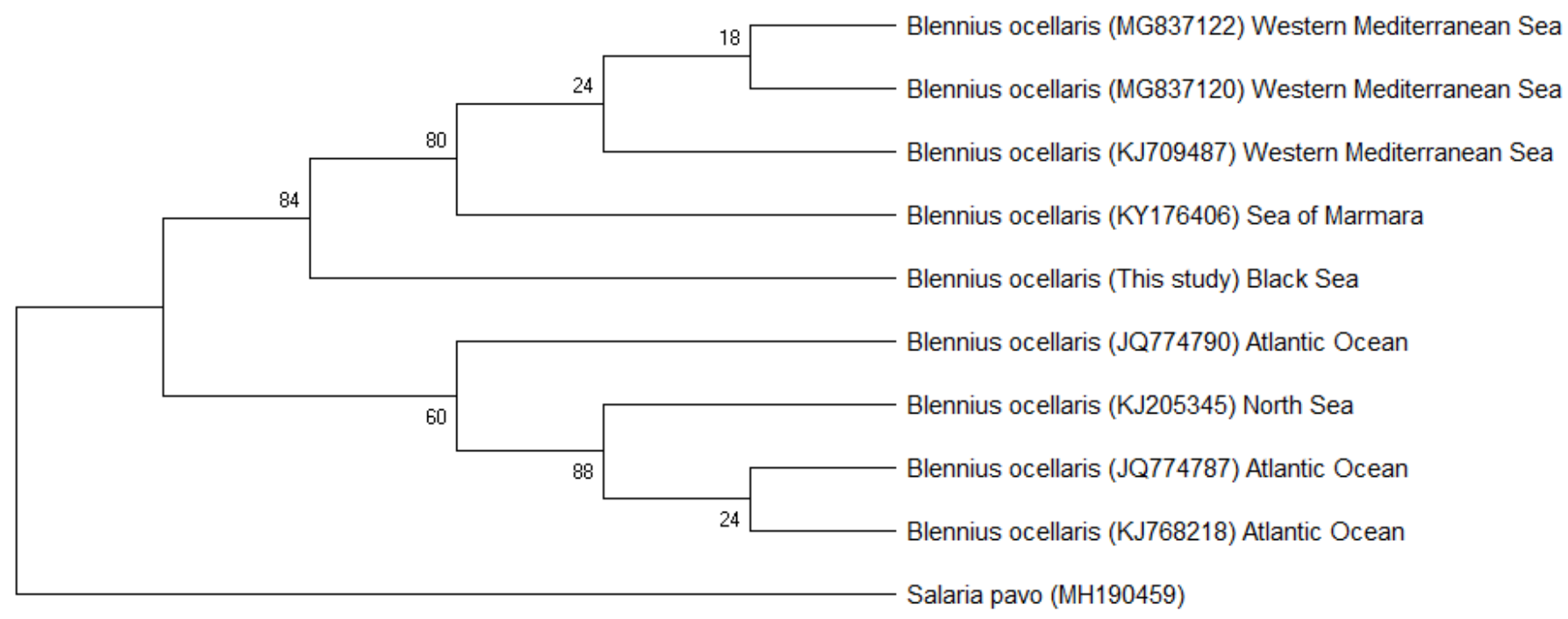

Figure 4. Maximum likelihood tree generated with the COI sequences of Blennius ocellaris along with reference sequences obtained from NCBI GenBank database 
Table 2. Length range of Blennius ocellaris from different studies in coastal waters in different seas

\begin{tabular}{ccclll}
\hline $\mathbf{T L}_{\text {min }}(\mathbf{c m})$ & $\mathbf{T L}_{\text {max }}(\mathbf{c m})$ & $\mathbf{N}$ & \multicolumn{1}{c}{ Region } & \multicolumn{1}{c}{ Sea } & \multicolumn{1}{c}{ References } \\
\hline 8.0 & 20.6 & 30 & Balearic Islands & Balearic Sea & Merella et al. (1997) \\
8.6 & 10.37 & 11 & & Aegean Sea & Kabasakal (1999) \\
12.9 & 15.3 & 3 & İskenderun Bay & Mediterranean Sea & Başusta and Erdem (2000) \\
11.8 & 13.3 & 4 & Edremit Bay & Aegean Sea & Torcu and Aka (2000) \\
5.3 & 14.1 & 117 & & Thracian Sea & Lamprakis et al. (2003) \\
4.1 & 9.6 & 43 & Mersin Bay & Mediterranean Sea & Çiçek et al. (2006) \\
11.2 & 13.7 & 15 & & Sea of Marmara & Bok et al. (2011) \\
6.0 & 11.0 & 69 & İzmir Bay & Aegean Sea & Acarlı et al. (2014) \\
7.5 & 15.3 & 35 & & Aegean Sea & Bilge et al. (2014) \\
5.5 & 16.5 & 279 & İzmir Bay & Aegean Sea & İlkyaz et al. (2018) \\
7.2 & 13.1 & 44 & & Sea of Marmara & Daban et al. (2020) \\
\hline TL $=10.52$ male & 1 & Ordu & Black Sea & Current study \\
TL $=10.40$ female & 1 & Ordu & Black Sea & Current study \\
\hline
\end{tabular}

\section{Conclusion}

The present study confirms the occurrence of butterfly blenny, B. ocellaris in the coastal area of the Black Sea. Little is known about the distribution, habitat and biological aspects of butterfly blenny in Turkey. Moreover, in the present study, B. ocellaris was genetically characterized for the first time in the Black Sea based on mtDNA gene sequences. The findings of the study contribute to better understand distribution of the species in the Black Sea and report first detailed data on biology, morphology, and reproduction of this species in Turkish coastal waters of the Black Sea.

\section{Compliance with Ethical Standard}

Conflict of interests: The authors declare that for this article they have no actual, potential or perceived conflict of interests.

Ethics committee approval: All authors declare that this study does not include any experiments with human or animal subjects. All applicable international, national and/or institutional guidelines for the care and use of animals were followed by the authors.

\section{Funding disclosure: -}

Acknowledgments: -

Disclosure: All authors contributed to the study conception and design. All authors read and approved the final manuscript.

\section{References}

Acarl, D., Kara, A., Bayhan, B. (2014). Length-weight relations for 29 fish species from Homa Lagoon, Aegean Sea, Turkey. Acta Ichthyologica et Piscatoria, 44(3), 249-257. https://doi.org/10.3750/AIP2014.44.3.09

Almada, F., Almada, V. C., Guillemaud, T., Wirtzs, P. (2005). Phylogenetic relationships of the north-eastern Atlantic and Mediterranean blenniids, Biological Journal of the Linnean Society, 86, 283-295.

https://doi.org/10.1111/j.1095-8312.2005.00519.x

Bagenal, T. (1978). Methods for assessment of fish production in fresh waters. Oxford: Western Printing Servis Ltd., p. 219-226 ISBN: 0632001259

Başusta, N., Erdem, Ü. (2000). A study on the pelagic and demersal fishes of Iskenderun Bay. Turkish Journal of Zoology, 24, 1-19 (in Turkish).

Bat, L., Erdem, Y., Ustaoğlu, S., Yardım, Ö., Satılmış, H.H. (2005). A study on the fishes of the central Black Sea coast of Turkey. Journal Black Sea/Mediterranean Environment, 11, 281-296.

Bilecenoğlu, M., Kaya, M., Cihangir, B., Çiçek, E. (2014). An updated checklist of the marine fishes of Turkey. Turkish Journal of Zoology, 38, 901-929. 
http://dx.doi.org/10.3906/zoo-1405-60

Bilge, G., Yapıcı, S., Filiz, H., Cerim, H. (2014). Weightlength relations for 103 fish species from the Southern Aegean Sea, Turkey. Acta Ichthyologica et Piscatoria, 44(3), 263-269.

https://doi.org/10.3750/AIP2014.44.3.11

Bok, T.D., Göktürk, D., Kahraman, A.E., Aliçli, T.Z., Acun, T., Ateş, C. (2011). Length-weight relationships of 34 fish species from the Sea of Marmara, Turkey. Journal of Animal and Veterinary Advances, 10(23), 3037-3042.

BSC (2021). The Commission on the Protection of the Black Sea Against Pollution (BSC), Black Sea Fishes Check List. http://www.blacksea-commission.org/_publ-BSFishList.asp (accessed: 25.06.2021).

Carrasson, M., Bau, M. (2003). Reproduction and gonad histology of Aidablennius sphynx (Pisces: Blenniidae) of the Catalan Sea (northwestern Mediterranean). Scientia Marina, 67(4), 461-469.

https://doi.org/10.3989/scimar.2003.67n4461

Coker, T., Cihangir, B. (2018). Ichthyoplankton of inner Part of Izmir Bay, Aegean Sea (2000-2005). Turkish Journal of Fisheries and Aquatic Sciences, 18, 57-67. https://doi.org/10.4194/1303-2712-v18 107

Costa, F. O., Landi, M., Martins, R., Costa, M. H., Carneiro, M., Alves, M. J., Steinke, D., Carvalho, G. R. (2012). A Ranking System for Reference Libraries of DNA Barcodes: Application to Marine Fish Species from Portugal, Plos One, 7(4), e35858.

https://doi.org/10.1371/journal.pone.003585

Çiçek, E., Avşar, D., Yeldan, H., Özütok, M. (2006). Length-weight relationships for 31 teleost fishes caught by bottom trawl net in the Babadillimani Bight (northeastern Mediterranean). Journal of Applied Ichthyology, 22, 290292.

https://doi.org/10.1111/j.1439-0426.2006.00755.x

Daban, İ.B., Arslan İhsanoğlu, M., İşmen, A., İnceoğlu, H. (2020). Length-weight relationships of 17 teleost fishes in the Marmara Sea, Turkey. KSU Journal of Aquaculture and Nature, 23, 1245-1256.

https://doi.org/10.18016/ksutarimdoga.vi.682467
Damalas, D., Maravelias, C.D., Katsanevakis, S., Karageorgis, A.P., Papaconstantinou, C. (2010). Seasonal abundance of non-commercial demersal fish in the eastern Mediterranean Sea in relation to hydrographic and sediment characteristics. Estuarine, Coastal and Shelf Science, 89(1), 107118.

https://doi.org/10.1016/j.ecss.2010.06.002

Di Natale, A., Bilecenoğlu, M., Bariche, M., Bizsel, C., Massuti, E., Williams, J., Craig, M. (2014). Blennius ocellaris. The IUCN Red List of Threatened Species 2014. e.T185126A1768546.

https://doi.org/10.2305/IUCN.UK.2014-

3.RLTS.T185126A1768546.en

Erazi, R.A.R. (1942). Marine fishes found in the Sea of Marmara and in the Bosphorus. Review of the Faculty of Science University of Istanbul, 7, 103-114.

Fischer, W., Schneider, M., Bauchot, M.L. (1987). Méditerranée et Mer Noire (Zone de Pêche 37). Rome: Fiches FAO d'identification des espèces pour les besoins de la pêche Rev 1. (in French).

Froese, R., Pauly, D. (Eds) (2019). FishBase. Retrieved from https://www.fishbase.org (accessed: 18.04.2021).

Gaygusuz, Ö., Gürsoy, Ç., Özuluğ, M., Tarkan, A.S., Acıpınar, H., Bilge, G., Filiz, H. (2006). Conversions of total, fork and standard length measurements based on 42 marine and fresh water fish species (from Turkish waters). Turkish Journal of Fisheries and Aquatic Sciences, 6, 79-84.

Gharaei, A. (2012). Morphometric and meristic studies of snow trout Schizothorax zarudnyi (Nikolskii, 1897) as a threatened endemic fish. World Journal of Fish and Marine Sciences, 4, 426-429.

https://doi.org/10.5829/idosi.wjfms.2012.04.04.63123

Haddon, M., Willis, T.J. (1995). Morphometric and meristic comparison of orange roughy (Hoplostethus atlanticus, Trachichthyidae) from the Puysegur Bank and Lord-HoweRise, New-Zealand and its implications for stock structure. Marine Biology, 123, 19-27. https://doi.org/10.1007/BF00350319

Hall, T.A. (1999). BIOEDIT: A user-friendly biological sequence alignment editor and analysis program for Windows 95/98/ NT. Nucleic Acids Symposium Series, 41, 95-98. 
Helfman, G.S., Collette, B.B., Facey, D.E. Bowen, B.W. (2009). The diversity of fishes: Biology, evolution, and ecology. West Sussex: Wiley-Blackwell, p. 720, ISBN: 978-1405-12494-2

İlkyaz, A.T., Metin, G., Soykan, O., Kınacıgil, H.T. (2018). Spawning season, first maturity length and age of 21 fish species from the central Aegean Sea, Turkey. Turkish Journal of Fisheries and Aquatic Sciences, 18, 211-216.

https://doi.org/10.4194/1303-2712-v18 124

Jakobsen, T., Fogarty, M., Megrey, A.B., Monksness, E. (2009). Fish reproductive biology: implications for assessment and management. London: Wiley-Blackwell, p. 429, ISBN: 978-1-118-75274-6

Kabasakal, H. (1999). Description of the feeding morphology and the food habits of the butterfly blenny, Blennius ocellaris Linnaeus, 1758, from north-eastern Aegean Sea (Turkey). Netherlands Journal of Zoology, 49(3), 177-187.

https://doi.org/10.1163/156854299505687

Knebelsberger, T., Landi, M., Neumann, H., Kloppmann, M., Sell, A.F., Campbell, P.D., Laakmann, S., Raupach, M.J., Carvalho, G.R., Costa, F.O. (2014). A reliable DNA barcode reference library for the identification of the North European shelf fish fauna, Molecular Ecology Resources, 14 (5), 1060-1071.

https://doi.org/10.1111/1755-0998.12238

Kumar, S., Stecher, G., Li, M., Knyaz, C., Tamura, K. (2018). MEGA X: Molecular evolutionary genetics analysis across computing platforms. Molecular Biology and Evolution, 35(6), 1547-1549.

https://doi.org/10.1093/molbev/msy096

Lamprakis, M.K., Kallianiotis, A.A., Moutopoulos, D.K., Stergiou, K.I. (2003). Weight-length relationships of fishes discarded by trawlers in the North Aegean Sea. Acta Ichthyologica et Piscatoria, 33(2), 145-152.

https://doi.org/10.3750/AIP2003.33.2.04

Landi, M., Dimechi M., Arculeo, M., Girolama, B., Martins, R., Carneiro, M., Carvalho, R., Lo Brutto, S., Costa, F.O. (2014). DNA Barcoding for Species Assignment: The Case of Mediterranean Marine Fishes, Plos One, 9, e106135. https://doi.org/10.1371/journal.pone.0106135

Merella, P., Quetglas, A., Alemany, F., Carbonell, A. (1997). Length-weight relationship of fishes and cephalopods from the Balearic Islands (western Mediterranean). Naga ICLARM Q, 20, 66-68.

Moosleitner, H. (1988). The blennies of the Peninsula Chalkidiki (GR) and their distribution in the eastern Mediterranean (Pisces: Teleostei: Blennioidea). Thalassographica, 11(1), 27-51.

Murua, H., Kraus, G., Saborido-Rey, F., Witthames, P.R., Thorsen, A., Junquera, S. (2003). Procedures to Estimate Fecundity of Marine Fish Species in Relation to Their Reproductive Strategy. Journal of Northwest Atlantic Fishery Science, 33, 33-54.

https://doi.org/10.2960/J.v33.a3

Palumbi, S.R. (1996). Nucleic acids II: the polymerase chainreaction. In: Hillis, D.M., Moritz, C., Mable, B.K. (Eds.), Molecular Systematics. Sinauer Associates, Sunderland, pp. 205-247.

Rass, T.S. (1987). Present status of the composition of the Black Sea ichthyofauna. Journal of Ichthyology, 27, 64-72.

Slastenenko, E.P. (1959). Zoogeographical review of the Black Sea Fish Fauna. Hydrobiologia, 14, 177-188.

https://doi.org/10.1007/BF00042598

Torcu, H., Aka, Z. (2000). A study on the fishes of Edremit Bay (Aegean Sea). Turkish Journal of Zoology, 24, 45-61.

Turan, C. (2004). Stock identification of Mediterranean horse mackerel (Trachurus mediterraneus) using morphometric and meristic characters. ICES Journal of Marine Science, 61, 774-781.

https://doi.org/10.1016/j.icesjms.2004.05.001

Uiblein, F., Heemstra, P.C. (2010). A taxonomic review of the Western Indian Ocean goatfishes of the genus Upeneus (Family Mullidae), with descriptions of four new species. Smithiana Bulletin, 11, 35-71.

https://doi.org/10.1080/17451000.2013.850515

Vecchioni, L., Marrone, F., Belaiba, E., Tiralongo, F., Bahri-Sfar, L., Arculeo, M. (2018). The DNA barcoding of Mediterranean combtooth blennies suggests the paraphyly of some taxa (Perciformes, Blenniidae). Journal of Fish Biology, 94, 2, 339-344.

https://doi.org/10.1111/jfb.13897 
Ward, R.D., Zemlak, T.S., Innes, B.H., Last, P.R., Hebert, P.D.N. (2005). DNA barcoding Australia's fish species. Philosophical Transactions of the Royal Society B: Biological Sciences, 360, 1847-1857.

https://doi.org/10.1098/rstb.2005.1716

Watson, W. (2009). Larval development in blennies. In R.A. Patzner, E.J. Gonçalves, P.A. Hastings \& B.G. Kapoor (Eds.)
The biology of blennies (p. 309-350). New Hampshire, USA: Science Publishers. ISBN: 9781578084395

Zander, C.D. (1986). Blenniidae. In P.J.P. Whitehead, M.L. Bauchot, J.C. Hureau, J. Nielsen \& E. Tortonese (Eds). Fishes of the north-eastern Atlantic and Mediterranean (p. 1096-1112). Paris, Spain: UNESCO. ISBN: 9789230023089 